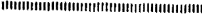 \\ 論文

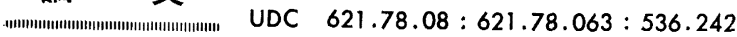 \\ 高温鋼板浸漬冷却時の熱伝達現象および熱伝達に 及ぼす攪挥の影響*
}

\author{
三塚 正志**. 福 田 敬 㸚**
}

\section{Heat Transfer Phenomena in Immersion Cooling of Heated Steel Plate and Influence of Water Stirring on Heat Transfer}

\author{
Masashi Mrtsutsuka and Keiji Fukuda
}

\section{Synopsis :}

When an immersion method is used for the cooling of heated steel products, it is important that the characteristics of this method are made clear. In order to measure the values of heat transfer coefficient between a specimen and coolant, and to clarify the influence of coolant stirring on heat transfer, $28 \times 550 \times$ $1000 \mathrm{~mm}^{3}$ steel plates of about $930^{\circ} \mathrm{C}$ have been immersed into still water or stirred water.

The main results obtained are summarized as follows:

(1) When a specimen is immersed vertically into water, the maximum of heat transfer coefficient between the specimen and water $(\alpha)$ is, in $\mathrm{kcal} / \mathrm{m}^{2} \cdot \mathrm{h} \cdot \mathrm{deg},(5-7) \times 10^{3}$ for still water, $(7 \sim 9) \times 10^{3}$ for stirred water by air flow, and $(10 \sim 12) \times 10^{3}$ for stirred water by water flow.

(2) In a vertical immersion into still water, $\alpha$ is considered to be a function of the surface temperature of a specimen, $\theta_{s}$, and the height from the lower edge, $\mathrm{H}$, as indicated below.

$\alpha=10\left(a+b \cdot \theta_{\mathrm{s}}\right) \cdot[1.0-k(H-10)]$

Where $a, b$, and $k$ are constants which depend on $\theta_{s}$.

(3) When a specimen is immersed vertically into still water, $\alpha$ decreases with increasing the size of the specimen.

(4) The stirring of coolant by fluid flow is effective for the accelaration of the heat transfer and the water flow method is superior to the air flow one.

\section{1. 緒言}

実用鋼材を熱処理または泠却時間短縮のため強制泠却 する場合, 均一な材質を得ることと良好な形状を保つこ とが重要だから，この泠却には，均一性と対称性が要求 される，その上，厚肉鎡枋の焼入れの場合には，大きな 冷却能力も要求される. 前報》に記述したように, 静止 水への浸漬冷却においては, 鋼材内各位置での熱伝達現 象が相違するため, 冷却の均一性と対称性は，なかなか 得られない,したがつて，鋼材の製造工程に浸漬泠却を 用いる場合には，冷却の均一性と対称性を得る方法を蓝 じなければならない，対称性を有する鋼板や丸鋼は，静 止水に垂直に浸漬すれば，面または軸刘称に冷却され る.これに対し, 鋼板の水平浸瀆㗪しては, 上下面の 冷却能力を等しくするため, 冷却水の強制㩜拌が行なわ
れる，この場合，各位置での泠却能力を上限に近づける ことによつて, 冷却の均一性・対称性と強化を同時に狙 らわけである。強制掜掉には, 被冷却体を動かす方法, 泠却水を機械的に流動させる方法または冷却水中に流体 （水や空気）を噴出させる方法などが使用されている. たとえば，多賀谷らは，18-8 鋼管 $(1 \cdot 1 / 2 B)$ の中に円 錐状の先端を有する銀棒 $(15 \mathrm{~mm} \phi)$ をセットし，水や 油の流速が熱伝達に及ぼす効果を調べている2).しかし， 大形鋼材を静止水に浸漬冷却する時の熱伝達の大きさや その分布，強制掜找が熱伝達に及ぼす効果などはほとん ど定量化されていない.

以上のような理由から，約 $930^{\circ} \mathrm{C}$ に加熱した $28 \times$ $550 \times 1000 \mathrm{~mm}^{3}$ 鋼板を $20 \sim 30^{\circ} \mathrm{C}$ の泠却水に垂直また は水平に浸漬し, 鋼板と泠却水間の熱伝達率とその分布 および流体噴出鄮拌法（水と空気）の㩭择効果を定量的

* 昭和47年 10 月本会講演大会にて発表 昭和51年12月13日受付 (Received Dec. 13，1976)

** 新日本製鉄(株)生産技術研究所 (Process Technology R \& D Laboratories, Nippon Steel Corp., 1-1 Edamitsu Yahatahigashi-ku Kitakyushu 805) 


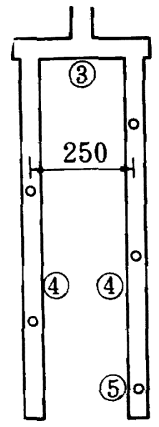

$\mathrm{B}-\mathrm{B}^{\prime}$

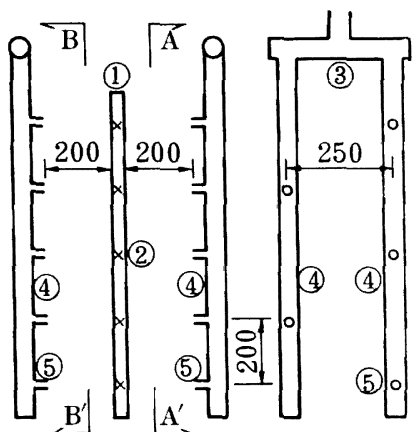

A- $\mathbf{A}^{\prime}$ (a) Water stirring method

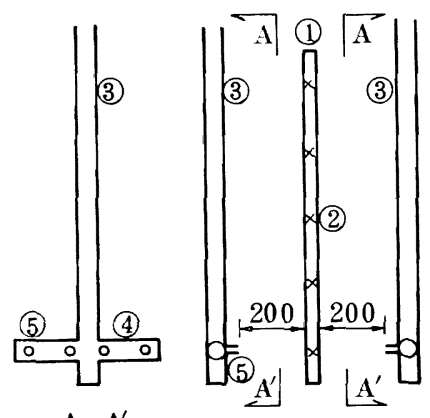

$\underline{A-A^{\prime}}$

(b) Air stirring method

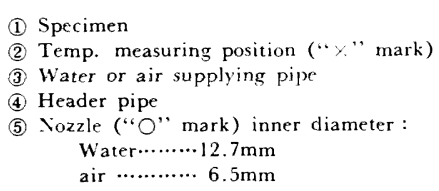

Fig. 1. Schematic diagram of the stirring methods of cooling water in a vessel.

に調ベる実験を行なつた。

\section{2. 実}

験

\section{$2 \cdot 1$ 実験装置}

冷却装置は， $1300 \mathrm{~mm} \square \times 1300 \mathrm{~mm} \mathrm{~h}$ の鎡板製水槽 で，その中に冷却水㹂挷用の水ノズルまたは空気ノズル を設置した。水ノズルは, 内径 $12.7 \mathrm{~mm}$ の直管で, 試 料の両側に設置し，ノズル·試料間距嚁は $200 \mathrm{~mm}$ であ る.ノズルは, 片側 5 本で, その位置は, Fig. 1 に示す ように, 試料の測温点に対応している. 空気ノズルは, 内径 $6.5 \mathrm{~mm}$ の直管で, 試料の両側の対称位置に 4 本 ずつ設置した。ノズルは，試料下端より $100 \mathrm{~mm}$ 上方 で, 試料表面から $200 \mathrm{~mm}$ の位置に，120 mm 間隔で 設置した。なお，試料を所定の位置に浸漬するため，水

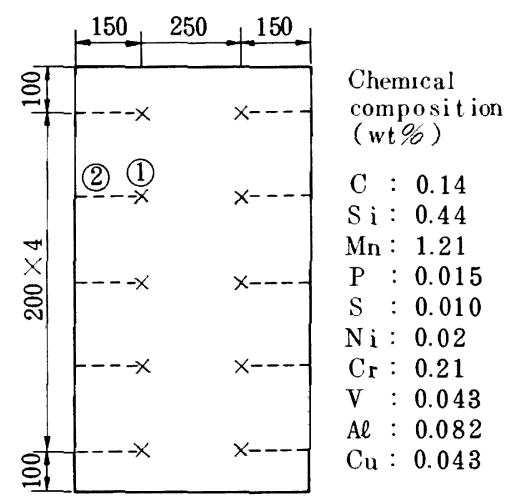

(1) Temp. measuring position (Center of thickness) (2) Hole for thermocouple (diameter : $3.5 \mathrm{~mm}$ ) Thickness of specimen : $28 \mathrm{~mm}$

Fig. 2. Specimen.

槽の中にガイドを設置した。

\section{2 試 料}

試料は, $28 \times 550 \times 1000 \mathrm{~mm}^{3}$ の低炭素銅板であり, その成分を Fig. 2 に示寸. 测温位置は，Fig. 2 に示す 10力所で，測温面は，厚さ方向の中央である.

\section{$2 \cdot 3$ 実験方法}

試料のさびやスケールをグラインダーで除去し, 台車 式電気炉 (雲囲気制御なし) で加熱する. 約 $930^{\circ} \mathrm{C} に$ 加熱した試料を垂直または水平に吊り，スケールを簡単 に除去した後, $200 \mathrm{~mm} / \mathrm{s}$ の速度で，静止水または缷捧 水に浸漬する. 水㹂捧の場合, Fig. 1 と Fig. 2 亿示す ように, 測温点の半分 ( 5 力所) は嘪流中心に, 他の半 分は互に隣接する噴流の中間に存在する、測温には, $\mathrm{CA}$ 熱電対 (素線径: $0.6 \mathrm{~mm}$ ) を用い，温接点を試料 に点溶接した。なお, 熱伝達率の算出法は前報1と同じ である。

\section{3. 実 験 結 果}

\section{$3 \cdot 1$ 表面温度と熱伝達率（垂直浸漬）}

試料表面温度 $\theta_{s}$ が熱伝達率 $\alpha$ に及ぼす効果を Fig. 3 (静止水) 上Fig. 4 (㩜拌水) に示すが，その傾向は， 前報1)の結果とほぼ同じである。これらの図から，

（i）静止水浸漬冷却時の $\alpha$ は， $\theta_{s}$ の関数であり，そ の極大值は, $\theta_{s}: 200 \sim 350^{\circ} \mathrm{C}$ の範囲に存在し, その值 は, $(5 \sim 7) \cdot 10^{3} \mathrm{kcal} / \mathrm{m}^{2} \cdot \mathrm{h} \cdot \operatorname{deg}$ であること,

（ii）静止水没漬冷却時の $\alpha$ は， $\theta_{s}$ の上昇につれて， $\theta_{s}<$ 約 $200^{\circ} \mathrm{C}$ の範囲では増大し, $\theta_{s}>$ 約 $350^{\circ} \mathrm{C}$ の範 囲では減少すること,

（iii）鄮拌水浸漬冷却時の $\theta_{s}$ と $\alpha$ の関係も，その傾向 


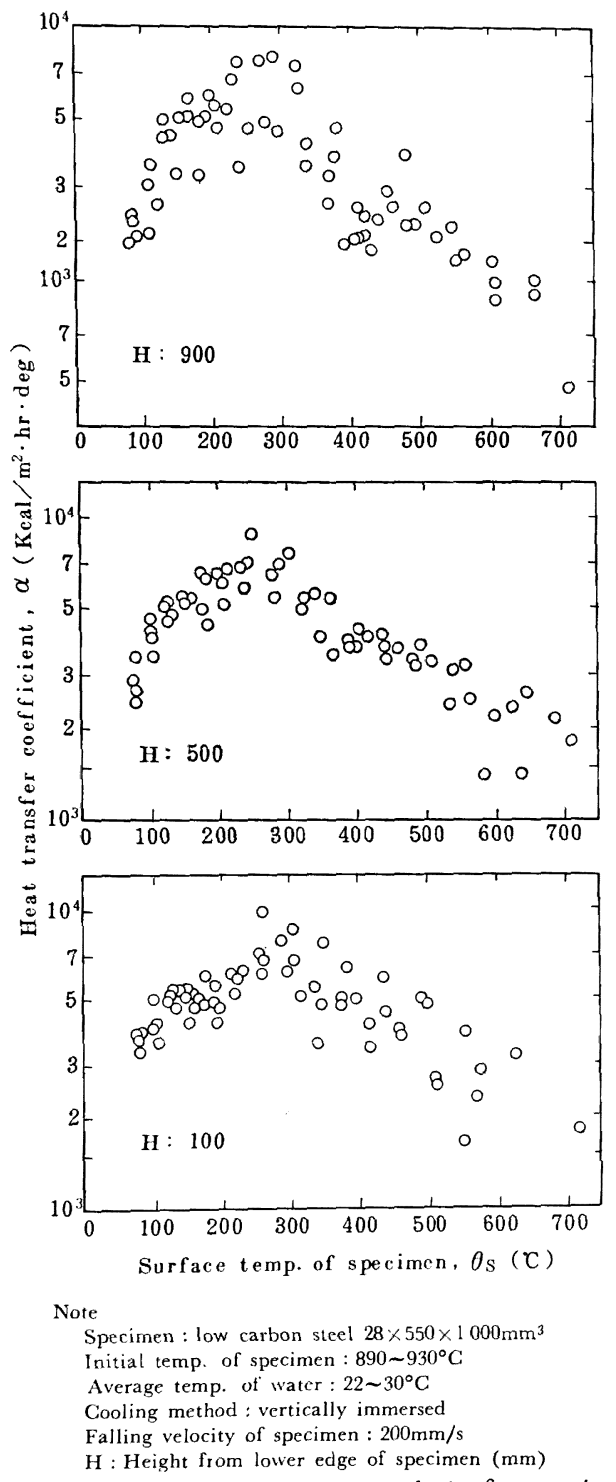

Fig. 3. Relation between $\alpha$ and $\theta_{s}$ for vertical immersion cooling of a heated steel plate into still water.

は，静止水の場合とほぼ類似していること， がわかる.上記（i ）（iii）の現象は，高温鋼材を水冷 する時の基本的特性である.

\section{$3 \cdot 2$ 試料内位置と熱伝達率（垂直漫漬）}

静止水に高温試料を重直に浸漬すると, 試料からの熱 で加熱された温水や発生した蒸気泡は, 試料にそつて上 昇する.その結果, 試料の下部近傍には冷たい水が，上 部近傍には，流動の激しい温水と蒸気泡が存在すること

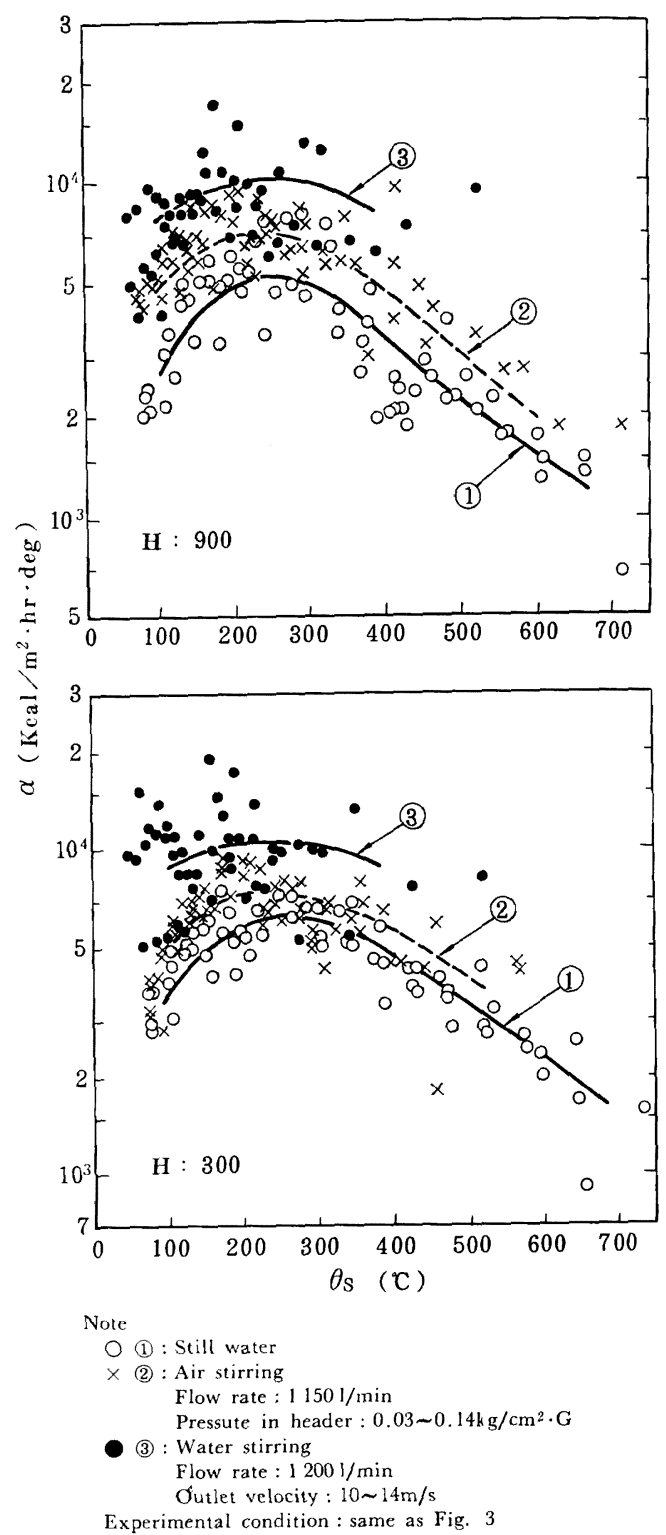

Fig. 4. Influence of the forced stirring of cooling water on cooling effect.

になる（前報1）の Photo. 1 参照).この現象において， 熱伝達に関与する主な要因としては, 冷却水の昇温と流 動，および蒸気泡の存在が考えられる.これらの効果を 把握するため, $20 \sim 30^{\circ} \mathrm{C}$ の静止水に高温の試料を垂直 に浸漬し, 試料下端からの距唯 $H$ と熱伝達率 $\alpha$ との関 係を求め, その一部を Fig. 5 に示す. この図から, (i) $\theta_{s}: 150 \sim 350^{\circ} \mathrm{C}$ の範囲では， $\alpha$ は $H$ の影響をほ とえど受けないこと， 


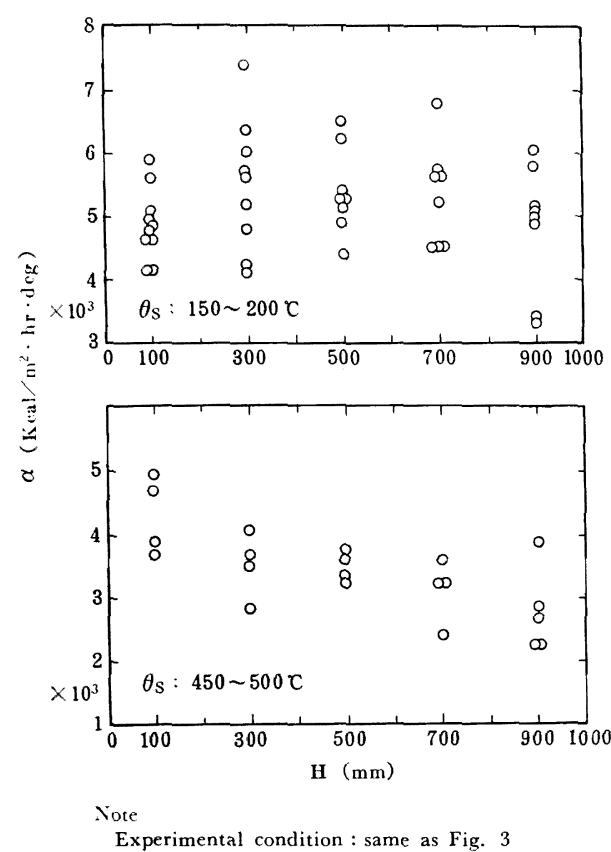

Fig. 5. Relation between $\alpha$ and $H$ for vertical immersion cooling into still water.

(ii） $\theta_{3}$ が高くなると， $\alpha$ は，Hの增大につれて減少 するこレ

がわかる.（i）の場合には，試料表面で冷却水が激し く核沸騰して熱伝達を促進するから, 泠却水の温度や流 動の効果が相対的に低下し，この結果，Hの影響が非常 に少さくなるものと考えられる。一方，(ii)の場合には， 蒸気膜が熱伝達を阻害する温度領域だから, 冷却水の昇 温すなわち $H$ の影響を受けるものと考えられる.

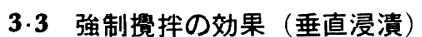

高温鋼材を静止水に浸漬冷却する時, その冷却効果 は，上下面や高さ方向で異なる．この現象は，浸漬泠却 の実用化に際し，大きな障害となる。この不都合は，冷 却水を強制覧拌し，鋼材内各位置での熱伝详を等しくす ることによつて解決できるはずである. 一方, 強制摼排 は, 冷却強化法としても有効である. 以上のような理由 から，Fig. 1 に示す流体噴出法で泠却水を鄮找し， そ の効果を測定した．実験結果を Fig. 4 と6に示す.こ れらの図から，

（i）流体掜拌により，泠却能力は，かなり增大するこ 之,

(ii）（i）の増分割合は，今回用いた流量の端囲内では， “水㩇捧>空気攪拌”であること，

（iii）水㨨拌による冷却能力の增分は, 平均唶射流量が

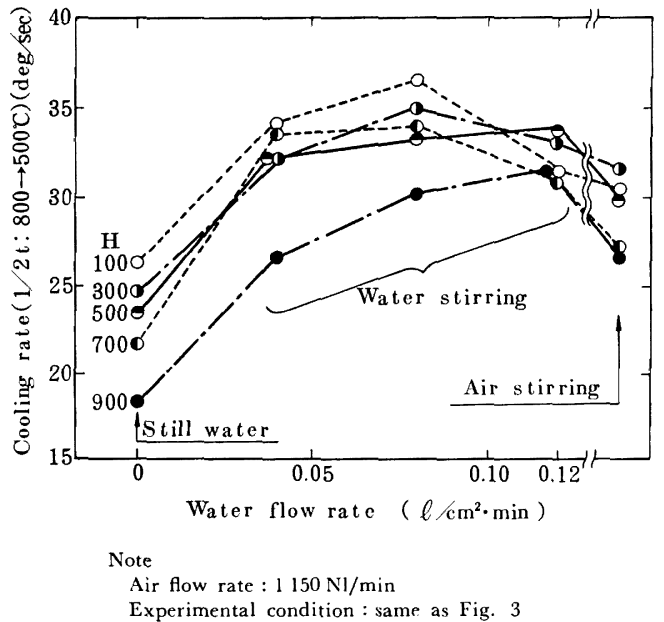

Fig. 6. Influence of the water flow rate for forced stirring on the cooling rate.

約 $0.04 \mathrm{l} / \mathrm{cm}^{2} \cdot \min$ で飽和する傾向があること，

（iv）今回用いた流体㨨找法は，高さ方向の泠却効果を 均一化するには適さないこと， がわかる。

水䁂拌の場合，流量を増せば，強力なジェット泠却に 近づくわけだから，（i）の事実は，容易にうなずける． (iii) と（iv）は互に矛盾するわけだが，今回の方法で は，ノズル配置が不適切なため，泠却能力が真の飽和值 まで達していないものと考えられる.

一方，空気掜拌の場合，流量の少ない䇛囲では，泠却 能力は, 流量に比例して増大寸る.しかし, ある流量以 上では, 泠却水と試料との直接接促量が減少与るため, 冷却能力は, 流量の增大についれて, 逆に小さくなるは ずである.したがつて, 空気掜找の場合には, 泠却能力 を最大にする流量範囲が存在するものと考えられる. 今 回用いた流量が，どの範囲に相当するのかは不明であ る.

\section{4 上下面の冷却効果（水平浸漬）}

清泠却の場合，上下面の熱伝達の差は，高さ方向以 上に大きく，これが実用化に際して大きな障害となる. $28 \times 220 \times 220 \mathrm{~mm}^{3}$ 試料を $84^{\circ} \mathrm{C}$ の静止水に水平に没漬 した時の沸騰状沉を Photo. 1 に示す. この写真から，

（i）上面で発生した蒸気は，スムースに䜅脱・浮上す ること,

（ii）下面で発生した蒸気は，層状になつて試料下部に 存在し，その量が多くなると，試料の四周から間久的 に離脱・浮上すること，

(iii）下面に蒸気が安定して存在している時，厚さ方向 


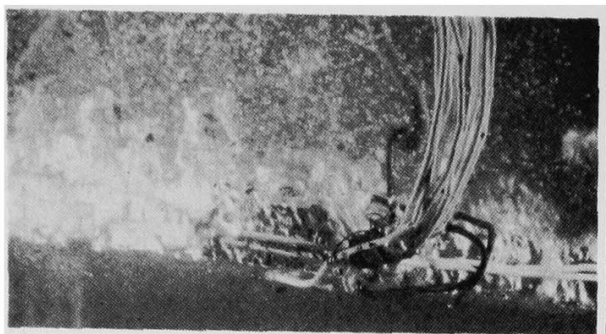

$t: 1 \mathrm{sec}$

(1) 923 , (2) 936, (3) $929^{\circ} \mathrm{C}$

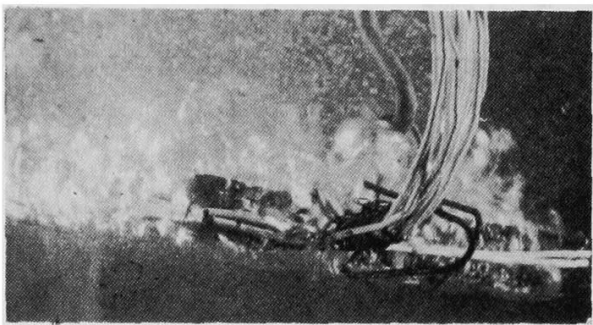

$t: 25$

(1) 689, (2) 803, (3) 810

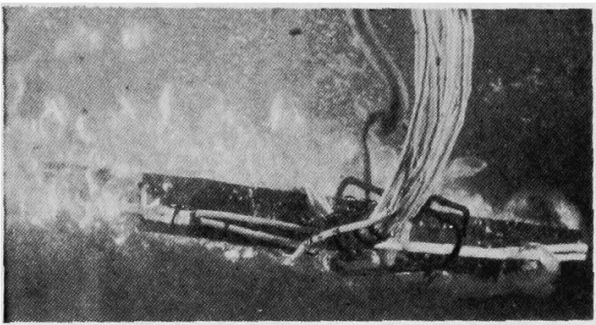

(1) 524 , (2) 650 , (3) 696

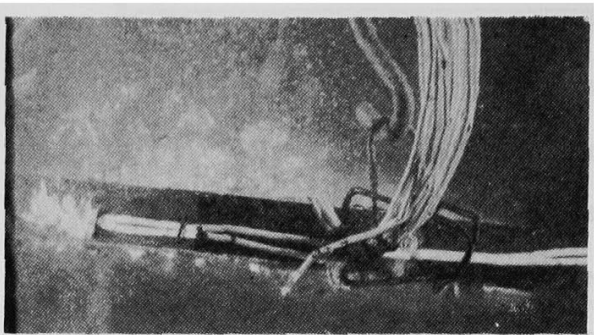

$t: 75$,

(1) 353 , (2) 452, (3) 578

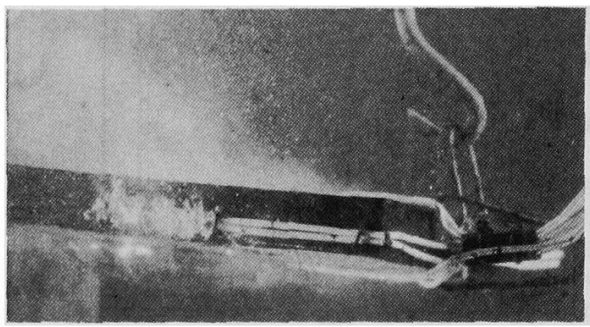

$t: 105$,

(1) 182, (2) 223 , (3) 297

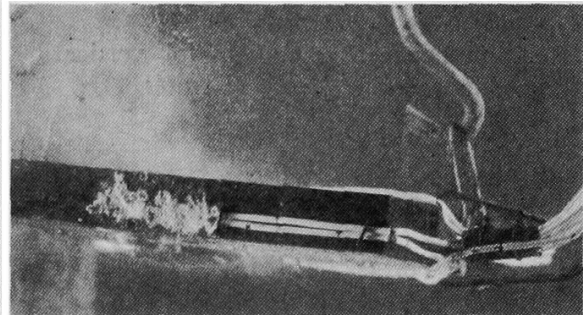

$t: 120$

(1) 132, (2) 137, (3) 150

Not

Specimen : low carbon steel, $28 \times 220 \times 220 \mathrm{~mm}^{3}$, Initial temp. : $936^{\circ} \mathrm{C}$, Water temp. : $84^{\circ} \mathrm{C}$

$t$ : time from immersion, Shutter speed : $1 / 1000$

Cooling method : horizontally immersed

Temp. measuring position :

(1) $\cdots \cdots . . .1 \mathrm{~mm}$ from upper surface in the neighbourhood of specimen cente

(2) $\cdots \cdots \cdots$....middle of thickness

(3) $\cdots \cdots \cdots 1 \mathrm{~mm}$ from lower surface

Photo. 1. Boiling state in a process of horizontal immersion cooling into still water.

の温度分布は，“下面>中央>上面”であること， がわかる.（i ～（ iii）の現象は, 試料の下面に存在す る蒸気層が，熱伝達の障害になつていること定実証して いる.なお，この試料の冷却曲線は，前報1)の Fig. 6 を参照されたい。

次に, $28 \times 550 \times 1000 \mathrm{~mm}^{3}$ 試料岂 $20 \sim 30^{\circ} \mathrm{C}$ の静止 水に水平に浸漬した時の泠却曲線を Fig. 7 に示す. こ の図によると，厚さ方向の温度分布は，“下面二中央> 上面”である.今回上ほぼ同じ条件で浸漬した $28 \times 220$ $\times 220 \mathrm{~mm}^{3}$ 試料のそれは, “中央>下面>上面”である (前報 ${ }^{1)}$ Fig. 6 参照). この温度分布の違いは, 試料の
大きさに依存するわけである、この事実は，大形鋼材の 浸漬冷却に際しては，上下面の泠却効果の違いを十分考 虑すべきこと宗唆している。

\section{4. 考察}

\section{$4 \cdot 1$ 高さ方向の熱伝達分布}

前報1)の垂直浸漬時の写真から明らかなように，蒸気 泡や加熱された水は，試料にそつて上昇する.したがつ て，試料下端からの距蜼 $H$ が大きくなるにつれて，試 料近浐の泠却水は昇温し，その流動は激しくなる。この 結果, 水温や流動状態に影響される熱伝達率 $\alpha$ は, $H$ の 


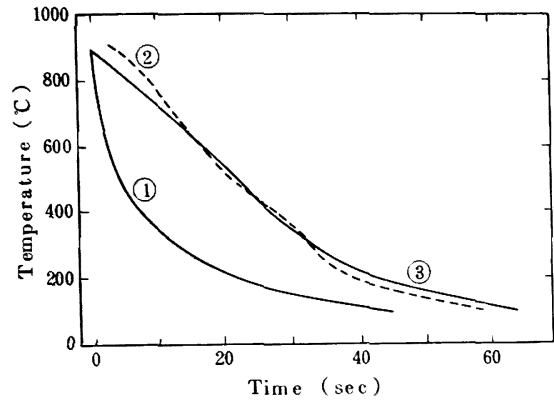

Note

Specimen : low carbon steel, $28 \times 550 \div 1000 \mathrm{~mm}^{3}$ Initial temp. : $905 \sim 925^{\circ} \mathrm{C}$

Water temp. : $26 \sim 28^{\circ} \mathrm{C}$

Depth from water surface : $700 \mathrm{~mm}$

Temp. measuring position :

(1) ……1 $\mathrm{mm}$ from upper surface

2........middle of thickness

(3........ $1 \mathrm{~mm}$ from lower surface

Falling velocity of specimen : $200 \mathrm{~mm} / \mathrm{s}$

Cooling method : horizontally immersed

Temp. of specimen : average of two experiments

Fig. 7. Cooling curves of a steel plate horizontally immersed into still water.

関数になるはずである.

実験結果によると，核沸騰の激しい温度領域での $\alpha$ は，Hの影響を添とえど受けない（Fig. 5 の $\theta_{s}: 150$ $200^{\circ} \mathrm{C}$ 参照). もともと, この温度領域では, 水温の影 響が小さく, (前報1) 参照), その上核沸騰によつて, 試 料近傍の水が局部的に激しく流動するため, 上昇流の効 果が相対的に小さくなるものと考えられる.

これに対し，表面温度 $\theta_{s}$ が高くなると，試料表面に 蒸気膜が形成されるようになる。この温度領域では, 蒸 気の発生のしやすさ，換言すれば， $\theta_{s}$ が高いほど熱伝 達は阻害される。それゆえ， $H$ の增大につれて， $\alpha$ は 減少するものと考えられる (Fig. 5 の $\theta_{s}: 450 \sim 500^{\circ} \mathrm{C}$ 参照).

次に，Hが $\alpha$ 亿及流す効果を定量化する. $H$ の効果

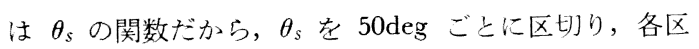
間内では， $H$ と $\alpha$ の関係を直線と仮定する. 寸なわち， $H: 10 \mathrm{~cm}$ :おける $\alpha$ の值 $\alpha_{10}$ を基準にし， $H: H$ に おける

$$
\begin{gathered}
\alpha=\alpha_{10} \cdot[1.0-k \cdot(H-10)] \\
k: \text { 定 数 }
\end{gathered}
$$

Łする.ここで， $\alpha_{10}$ は， $\theta_{s}$ の関数で

$$
\begin{array}{r}
\alpha_{10}=10^{\left(a+b \cdot \theta_{s}\right)} \\
a, b \text { : 定 数 }
\end{array}
$$

である (前報1) 参照).（2）式を（1）式に代入与る上, $\theta_{s}: \theta_{s}, H: H$ の は,

$$
\alpha=\left[10^{\left(a+b \cdot \theta_{s}\right)}\right] \cdot[1.0-k \cdot(H-10)]
$$

Table 1. Constants of the experimental equation of $\alpha$ which represents the effects of $\theta_{S}$ and $\mathrm{H}$ in a process of vertical immersion cooling into steel water.

\begin{tabular}{c|c|c|c}
\hline $\begin{array}{l}\text { Range of } \\
\text { surface } \\
\text { temperature }\end{array}$ & \multicolumn{3}{|c}{ Value of constants } \\
\cline { 3 - 4 }$\left({ }^{\circ} \mathrm{C}\right)$ & $a$ & $b$ & $k$ \\
\hline $50 \sim 90$ & $2.640 \times 10^{\circ}$ & $5.271 \times 10^{-3}$ & \\
$90 \sim 110$ & 1.018 & 23.29 & \\
$110 \sim 150$ & 3.326 & 2.308 & $2.0 \times 10^{-3}$ \\
$150 \sim 200$ & 3.376 & 1.975 & 0.0 \\
$200 \sim 250$ & 3.550 & 1.104 & 0.0 \\
$250 \sim 300$ & 3.859 & 0.1306 & 0.5 \\
$300 \sim 350$ & 4.202 & -1.273 & 1.5 \\
$350 \sim 400$ & 4.342 & -1.676 & 3.0 \\
$400 \sim 450$ & 4.338 & -1.665 & 3.5 \\
$450 \sim 500$ & 4.342 & -1.674 & 3.5 \\
$500 \sim 550$ & 4.407 & -1.804 & 4.0 \\
$550 \sim 600$ & 4.435 & -1.855 & 5.0 \\
$600 \sim 650$ & 4.423 & -1.835 & 5.0 \\
$650 \sim 700$ & 4.129 & -1.382 & 5.0 \\
$700 \sim 750$ & 4.211 & -1.500 & 5.0 \\
$750 \sim 800$ & 3.761 & -0.8993 & 5.0 \\
& & & \\
\hline Exp & & &
\end{tabular}

*) Experimental equation : $\alpha=10^{\left(a+b \cdot \theta_{s}\right) \cdot[1.0-k \cdot(H-10)]}$

となる.ここで, 定数 $a, b$ および $れ$ は $\theta_{s}$ の関数だか

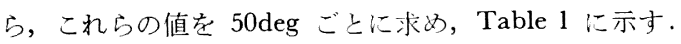
この表によると, $H$ の効果を示す $k$ の值は, 核沸騰域 $\left(\theta_{s}: 150 \sim 250^{\circ} \mathrm{C}\right)$ では $k: 0.0$ (H の効果なし) だが， $\theta_{s}$ が上昇するにつれて段々増大し， $\theta_{s}>550^{\circ} \mathrm{C}$ では $k$ : 5.0 となる. すなわち， $\alpha$ に及ぼす $H$ の効果は，水温 の効果とほぼ同じ傾向である(前報1)の Table 1 参照). この事実は，H の効果が，泠却水の流動状態よりも水 温上昇に依存する度合が大きいことを示㖫している.

今回用いた試料の高さは $1 \mathrm{~m}$ だが，生産現場では， 数 $\mathrm{m} \sim 10$ 数 $\mathrm{m}$ の鋼板を浸漬泠却しているから，このよ うに大きな鋼板に対しては，(3) 式を修正して使用せ 权快らない。

\section{2 試料寸法の効果}

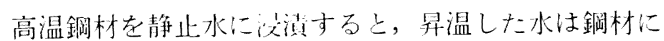
そつて上昇し, 泠たい新鮮な水が下部や周囲から流入す る.したがつて, 熱伝详の大きさは, 被冷却体の寸法き 形状に影盟されるはずである。高温鋼材をほぼ同じ条件 で静止水に垂直に渗漬佮却して得られた各研究者の熱伍 達率 $\alpha$ 索比較すると, 次表の通りである.

研究者間で $\alpha$ の算出法や計算に用いる鋼材の物性值が 異なるから，緟密な比較はできないが，試料寸法が熱伝

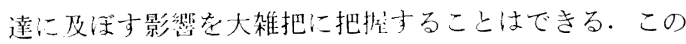
比較から，

（i） $\alpha$ の值は，試料が大きくなるにつれて小さくなる こ上,

(ii) $\alpha$ の極大值に対応する $\theta_{s}$ は，研究者間で相違す 


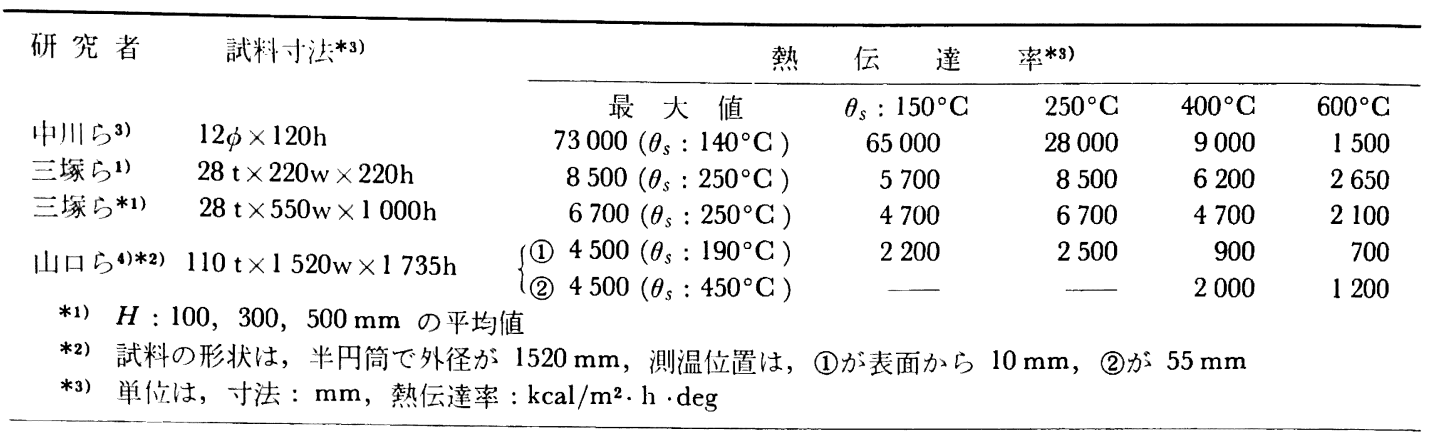

$$
\text { ること, }
$$

がわかる.（i ）については, 試料近傍の冷却水の流動状 態, 少体的には, 冷たい水の流入度合の影響と考えられ る.この事実は，小形試料で得られた $\alpha$ を用いて，1〜 $10 \mathrm{~m}$ オーダの実用鋼材の泠却曲線を計算する場合には, 寸泛刘果を考虑せ致ばならないことを示している。（ii） については, $\alpha$ の算出法, 用いた物性值の值, 測温位置 および試料の表面性状などが影響しているものと考えら れる、古なわち, 物性值については, 変態熱の放出状態 と温度伝導率の值が, 測定と計算の精度については測温 位置が，表面性状についてはスケールの付着状態が関係 する・

\section{3 摫找の効果}

泠却水を掜找寸る目的は, 試料近修の昇温水や蒸気泡 を除去し，冷たい水と置捘することおよび試料表面の䧲 気膜を破壊または除去し, 試料と水が直接接触する機会 を増し，これによつて，熱伝達を促進することである. 掜拌方法としては, 試料と冷却水間に相对速度を与えれ ばよいのだから，試料を動かすか泠却水を流動させれば よい，また，掜拌強さの指標としては，掜拌方法に依存 しない普遍性のある特性值, たとえば, レイノルズ数や 相対速度を用いるべきであるが，今回は，冷却水の流動 に流体噴出法を用いたから, 試料の単位面積人の平均噴 射流量で整理した。

潩水摳拌により， $\alpha$ の最大值 $\alpha_{\max }$, が約 $10000 \mathrm{kcal} /$ $\mathrm{m}^{2} \cdot \mathrm{h} \cdot \operatorname{deg} に$ (Fig. 5), 厚さ $28 \mathrm{~mm}$ 鋼板の泠却速度 （板厚中央）が 30〜 35deg/s に増大する事実から判断す ると (Fig. 6), 噴水鄮捧付浸漬冷却は, 水冷の泠却能力 の上限に近いものと考元られる，見方を変えると，唺射 流量の大きいシェット泠却やラそナ泠却の場合, 試料近 倍の冷却水の流動状態は, 今回の冷却法とほぼ同じだか ら，上記の事実は容易に理解できる.しかし，Fig. 6 に よると, 冷却速度は, 噴射流量が約 $0.041 / \mathrm{cm}^{2} \cdot \min て ゙$ 飽和しているが，ジェット冷却の飽和值は約 $0.21 / \mathrm{cm}^{2}$
· min である (前報1)の Fig. 7 参照). この相違は, 両 泠却法の違いによるものと理解すべきであろうが，詳細 は不明である.

一方，空気摼㧔の場合には，噴出した空気は，すべて 試料にそつて上昇するから，試料近傍の冷却水の㩭找度 合は非常に大きく，これが冷却効果を促進するわけであ る.しかし, 空気量が極端に多くなると, 空気が蒸気膜 と類似の作用をし，熱伝達の障害になることが予想され る.したがつて, 冷却効果を最大にする限界空気量が存 在するはずである、今回の実験では，この值を把握する ことはできなかつた。

Fig. 6 によると, 今回用いた二つの㩜拌方法は, 高さ 方向の熱伝澾を均一化するには適さないことがわかる.

\section{4 試料配置と熱伝達との関係}

前報1にも記述したように，平板試料を静止水に水平 に浸漬する時の板内温度分布は，“下面>上面”である。 下面の熱伝達は, 試料の下面をおおうように存在してい る蒸気層に強く影響される，したがつて，上下面の温度 差は，水温や試料寸法に依存するはずである。筆者らの 平板試料と山口ら 料を静止水に水平に浸漬する時, 試料寸法が熱伝達に及 ぼす効果を比較すると, 次表の通りである.

平板の結果によると，放熱量の “上面/下面” の比は, 試料が大きくなるにつれ，また，水温が高くなるにつれ て増大する.これは, Photo. 1 からも明らかなように, 試料が広いかまたは水温が高い時には，試料下部に存在 する蒸気層が安定化し，下面での熱伝達が阻害されるた めと考元られる.

一方, 半円筒試料の板内温度分布は, “上側>下側” で あり，平板とは逆の結果になつている．これは，半円筒 試料を下に凸の状態で浸漬するため，下面で発生した蒸 気が比較的スムーズに浮上でき，この結果，下面での熱 伝達が同じ寸法の平板試料の值より大きくなるものと考 えられる.その上，この試料は広いから，上面中央部(測 


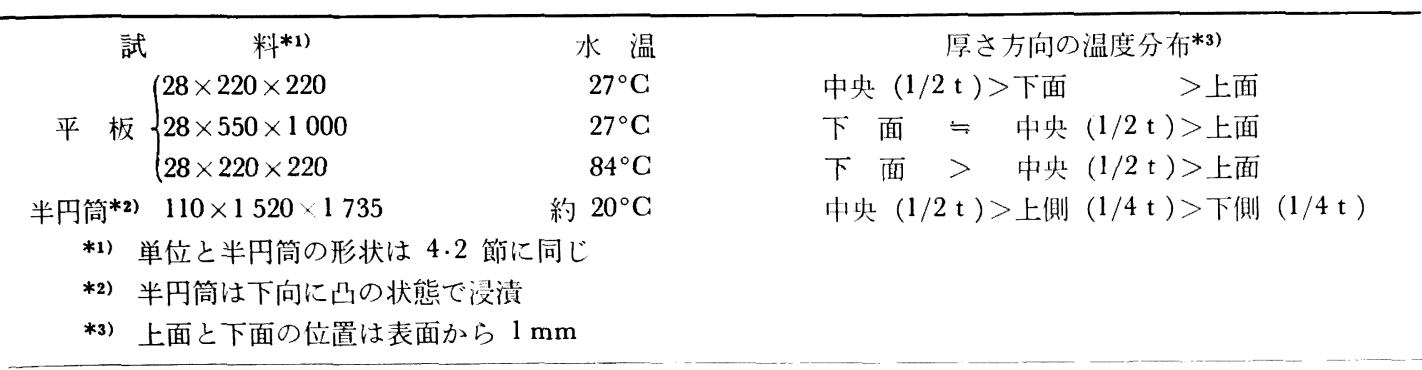

温位置）には，冷たい水が供給されにくく，この現象も 上面の熱任達を小さくする原因と考えられる.

このような現象が存在するから，平らな面を水平状態 で浸漬冷却する場合には, 泠却の強さと均一性の点か ら，細心の注意を払わねばならない。

\section{5. 結言}

実用鋼材の強制冷却に浸漬法を使用するに際しては， この冷却法の特性, 特に被冷却体各部の冷却効果を把握 することが重要である．したがつて，28×550×1000 $\mathrm{mm}^{3}$ 鋼板を約 $930^{\circ} \mathrm{C}$ に加熱し，20〜 $30^{\circ} \mathrm{C}$ の静止水と 鄮找水に垂直または水平に浸漬する実験を行ない，次の 結果を得た。

（1）静止水への垂直浸漬泠却時の熱伝澾率 $\alpha$ は, 表 面温度 $\theta_{s}$ と試料内位置の関数であり, 極大值は, $\theta_{s}$ : $200 \sim 350^{\circ} \mathrm{C}$ の範囲に存在し, $(5 \sim 7) \cdot 10^{3} \mathrm{kcal} / \mathrm{m}^{2} \cdot \mathrm{h}$. deg である.

（2）攪拌水（流体噴出攪拌）への垂直浸漬冷却時の $\alpha$ は, 静止水の場合より大きく，その極大值は， $\theta_{s}: 150$ $\sim 350^{\circ} \mathrm{C}$ の範囲に存在し, 空気摼抖が $(7 \sim 9) \cdot 10^{3}$, 水 攪拌が $(10 \sim 12) \cdot 10^{3} \mathrm{kcal} / \mathrm{m}^{2} \cdot \mathrm{h} \cdot \mathrm{deg}$ である.

（3）静止水への垂直浸漬泠却時の $\alpha$ は， $\theta_{s}$ と試料 下端からの距離 $H$ の関数であり，これらを数式化する $\llcorner$,

$$
\begin{aligned}
& \alpha=10^{\left(a+b \cdot \theta_{s}\right)} \cdot[1.0-k(H-10)] \\
& {[H]: \mathrm{cm}, a, b, k: \text { 定 数 }}
\end{aligned}
$$

である。この式の適用範囲は， $H<100 \mathrm{~cm}$ である.

（4）高温鋼材を $20 \sim 30^{\circ} \mathrm{C}$ の静止水に垂直に浸漬す る時の $\alpha$ は, 試料が大きくなるにつれて減少する. それ ゆえ，小さい試料で得られた $\alpha$ を大形鋼材に使用するに 際しては，寸法効果を考虑せねばならない。

（5）流体噴出掜拌法は，冷却能力を大幅に增強し，

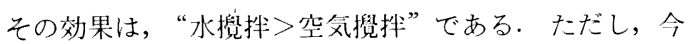
回用いた掜找法は, 高さ方向の熱伝達分布の均一化には 適さない。

（6）高温鋼板を静止水に水平に浸漬する時，熱任澾 量の“上面/下面”の比は，鋼板が広くなるか，丈たは 水温が高くなるにつれて増大寸る。

\section{交献}

1) 三塚正志, 福田敬爾：鉄と鋼，63 (1977) 6, p. 1008

2 ) 多賀谷正義, 田村今男: 金属学会誌, 22 (1958) 12 , p. 631

3 ) 中川有三, 吉田哲夫: 化学機械, 14 (1950) 7, p. 286

4 ) 山口富夫, 福栄久宜, 重松広次, 原田和明: 三菱 重工技報，6 (1969) 1，p. 30 